\title{
Keragaan Ukuran Dimensi Tubuh Hasil Persilangan Ayam Petelur dan Bangkok pada Fase Starter
}

\author{
Muhammad Amrullah Pagala ${ }^{1}$, La Ode Nafiu', Sri Maharani \\ ${ }^{1}$ Fakultas Peternakan, Universitas Halu Oleo \\ ${ }^{2}$ Alumnus Mahasiswa Fakultas Peternakan, Universitas Halu Oleo \\ Kampus Hijau Bumi Tridharma, Jl. H.E.A. Mokodompit, Anduonohu, Kendari 93232 \\ *Email korespondensi: amrullahpagala@uho.ac.id
}

(Diterima: 25-03-2019; disetujui 25-04-2019)

\begin{abstract}
ABSTRAK
Penelitian ini bertujuan untuk mengetahui karakteristik ukuran dimensi tubuh hasil persilangan resiprokal ayam petelur dan bangkok fase starter. Materi yang digunakan dalam penelitian yaitu 120 ekor ayam yang terdiri atas 60 ekor ayam PB (jantan petelur $\mathrm{x}$ betina bangkok) dan 60 ekor ayam BP (jantan bangkok x betina petelur). Data pengukuran ditabulasi, dianalisis secara deskriptif dan menggunakan Uji T. Parameter yang diamati adalah bobot badan, panjang badan, panjang rentang sayap, pertumbuhan dan lingkar dada. Hasil penelitian diperoleh secara umum pertambahan bobot badan, panjang badan, panjang shank, panjang rentang sayap, lingkar dada dan pertumbuhan ayam BP lebih besar dibandingkan ayam PB.
\end{abstract}

Kata Kunci: ayam bangkok,.ayam petelur, resiprokal, ukuran tubuh

\begin{abstract}
This study aimed to determine the characteristics of chicken body sizes resulted from reciprocal crossbreeding of laying hens and bangkok chicken on starter phase. The materials were 120 chickens including 60 chickens PB (male layer chicken x female bangkok chicken) and $60 \mathrm{BP}$ chickens (bangkok rooster $\mathrm{x}$ female layer chicken). Measurement data were tabulated, analyzed descriptively and T-Student. The parameters observed were body weight, body weight, body length, chest circumference, beak length, and wing pan length. The result showed that generally, body weight, body length, shank length, length of wing span, chest circumference and body weight gain of BP (bangkok rooster $\mathrm{x}$ female layer chicken) were greater than PB (layer chicken rooster $\mathrm{x}$ bangkok female).
\end{abstract}

Keywords: bangkok chicken, body size, laying chicken, reciprocal

\section{PENDAHULUAN}

Ayam bangkok merupakan salah satu ayam lokal dikarenakan telah cukup lama dibudidayakan di Indonesia. Umumnya ayam bangkok digunakan sebagai pejantan karena memiliki berbagai keistimewaan yaitu bentuk tubuh yang ramping dan memiliki daya tahan berlaga yang tinggi. Selain itu ayam bangkok mempunyai nilai ekonomi yang tinggi. Secara genetik pertumbuhan ayam bangkok relatif lambat, sehingga untuk mencapai bobot siap potong memerlukan waktu cukup lama. Demikian pula, untuk mendapatkan telur tetas yang seragam dalam jumlah banyak sulit diperoleh, hal tersebut berkaitan dengan produksi telur ayam bangkok yang rendah. Satu upaya yang dapat ditempuh untuk mengatasi hal tersebut adalah melalui persilangan dengan ayam yang memiliki produksi lebih tinggi, salah satunya menggunakan ayam ras petelur. Ayam ras petelur memiliki kelebihan dalam menghasilkan telur dengan jumlah yang 
banyak. Kualitas bibit ayam petelur saat ini telah memiliki pertumbuhan yang cepat, dewasa kelamin lebih dini dan puncak produksi yang dicapai lebih cepat (Suprijatna dan Natawihardja, 2004). Selain itu ayam petelur juga mempunyai kerangka tubuh yang besar. Namun ayam petelur memiliki bobot badan yang lebih ringan dan produksi daging rendah dikarenakan ayam ras petelur terseleksi untuk tujuan produksi telur dan bukan produksi daging.

Persilangan antara ayam bangkok jantan dengan ayam ras betina petelur (BP) dan resiprokalnya yaitu ayam ras petelur jantan dengan betina ayam bangkok (PB), akan diamati pengaruhnya melalui hasil persilangan yang menghasilkan bibit unggul, yang ditandai dengan bobot badan dan ukuran tubuh yang lebih besar. Ukuran tubuh dapat digunakan sebagai persyaratan dalam mencari bibit ternak yang baik sehingga pengukuran tubuh juga penting untuk dipelajari. Semakin besar rangka dalam ukuran normal diharapkan otot yang melekat juga semakin banyak sehingga menghasilkan potongan karkas yang lebih besar. Namun demikian, persilangan resiprokal ayam bangkok dan ayam ras petelur belum banyak diamati di Sulawesi Tenggara khususnya ukuran-ukuran tubuh pada tahap awal pertumbuhan. Berdasarkan latar belakang tersebut maka perlu dilakukan penelitian tentang "karakteristik ukuran-ukuran tubuh hasil silangan resiprokal ayam petelur dan bangkok fase starter".

\section{MATERI DAN METODE}

Penelitian ini dilaksanakan pada Bulan November 2017 sampai dengan Januari 2018, di jalan Haji Lamuse, Lorong Semeru Kelurahan Lepo lepo, Kecamatan Baruga, Kota Kendari.

Materi yang digunakan dalam penelitian ini adalah 120 ekor ayam yang terdiri atas 60 ekor ayam PB (jantan petelur $\mathrm{x}$ betina bangkok), 60 ekor ayam BP (jantan bangkok x betina petelur) dengan jenis kelamin berbeda. Peralatan yang digunakan dalam penelitian ini antara lain pita ukur (untuk mengukur sifat kuantitatif ayam Kampung super), timbangan (untuk menimbang bobot badan ayam), jangka sorong (untuk mengukur panjang tulang tarsometatarsus (shank), alat tulis (untuk mencatat hasil pengamatan) dan kamera (alat dokumentasi).

Ransum yang akan digunakan dalam penelitian ini adalah ransum komersil jenis BP11 Bravo yang diproduksi oleh PT. Charoen Pokphan Indonesia. Berikut kandungan nutrient bahan pakan dapat dilihat pada Tabel 1 .

Tabel 1. Kandungan nutrient bahan pakan

\begin{tabular}{lccccccc}
\hline $\begin{array}{c}\text { Bahan } \\
\text { pakan }\end{array}$ & $\begin{array}{c}\text { Presentase } \\
(\%)\end{array}$ & $\begin{array}{c}\text { EM } \\
(\mathrm{Kkal})\end{array}$ & $\begin{array}{c}\text { PK } \\
(\%)\end{array}$ & $\begin{array}{c}\text { SK } \\
(\%)\end{array}$ & $\begin{array}{c}\text { LK } \\
(\%)\end{array}$ & $\begin{array}{c}\text { Ca } \\
(\%)\end{array}$ & $\begin{array}{c}\text { P } \\
(\%)\end{array}$ \\
\hline Kosentrat & 35 & 1155 & 12,25 & 1,05 & 2,8 & 3,5 & 0,385 \\
Jagung & 50 & 1660 & 4,25 & 1,9 & 1,25 & 0,01 & 0,05 \\
Dedak & 15 & 277,5 & 1,8 & 11,85 & 1,23 & 0,018 & 0,075 \\
\hline \multicolumn{1}{c}{ Total } & 100 & 3092,5 & 18,3 & 14,8 & 5,28 & 3,528 & 0,51 \\
\hline
\end{tabular}

Sumber: Anggorodi (1985) dan Madani (2017)

Kandang yang akan digunakan adalah kandang kelompok. Pemberian pakan dilakukan setiap hari sebanyak 2 kali pada pukul 06.00 dan 16.00 WITA. Sedangkan pemberian air minum dilakukan secara ad libitum. Sifat-sifat kuantitatif yang diamati pada penelitian ini adalah bobot badan, panjang badan, panjang shank, dan panjang rentang sayap.

Data dianalisa secara deskriptif dan uji $\mathrm{T}$ student untuk mengetahui perbedaan peubah-peubah antara persilangan BP (jantan bangkok $\mathrm{x}$ betina petelur) dan $\mathrm{PB}$ (jantan petelur $\mathrm{x}$ betina bangkok).

$$
\mathrm{Uji} \mathrm{T}=\frac{X 1-X 2}{s \operatorname{gab}\left(\sqrt{\frac{s_{1}^{2}}{n 2}+\frac{s_{2}^{2}}{n 1}}\right)}
$$

Data kuantitatif dianalisis secara deskriptif yang terdiri dari nilai rataan, simpangan baku dan koefisien keragaman dari bobot badan, panjang femur, panjang tibia, panjang shank, panjang dada, panjang punggung, panjang rentang sayap, dan lingkar dada berdasarkan Steel dan Torrie (1995).

$$
S g a b=\sqrt{\frac{\left(\bar{x}_{1}-\overline{x_{2}}\right)^{2}}{n-1}}
$$




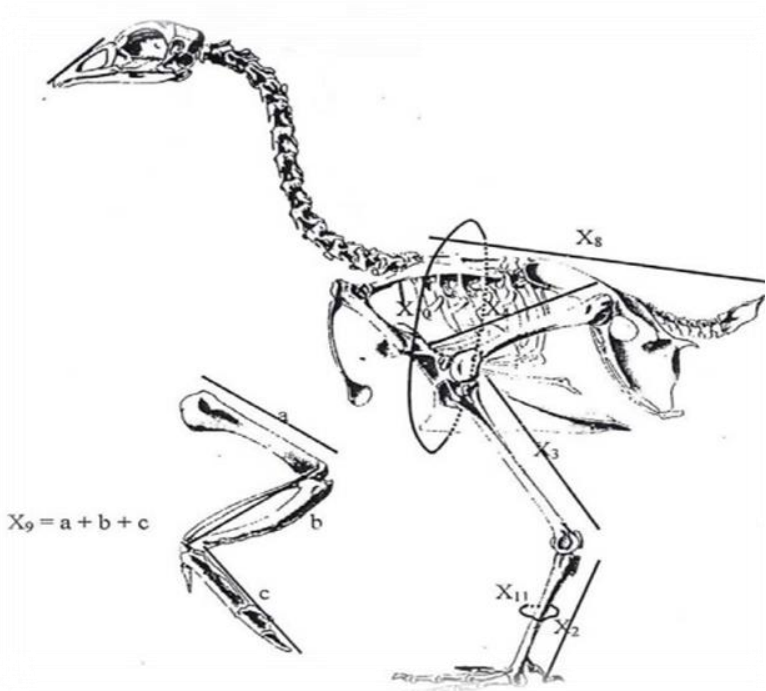

Keterangan: $\mathrm{X} 2=$ panjang tarsometatarsus; $\mathrm{X} 3=$ panjang tibia; $\mathrm{X} 4=$ panjang femur; $\mathrm{X} 8=$ panjang punggung; $\mathrm{X} 9$ = panjang sayap; $\mathrm{X} 10=$ lingkar dada; $\mathrm{X} 11$ = lingkar tarsometatarsus; $\mathrm{a}=$ panjang humerus; $\mathrm{b}=$ panjang radius dan ulna; $\mathrm{c}=$ panjang metacarpus

Gambar 1. Bagan Bagian-bagian Tubuh Ayam (Tarigan, 2010)

\section{Bobot Badan}

Hasil pengamatan bobot badan ayam hasil persilangan PB (Jantan ras petelur $\mathrm{x}$ betina bangkok) dan ayam $\mathrm{BP}$ (jantan bangkok $x$ betina ras petelur) Fase Starter disajikan pada Tabel 2. Berdasarkan hasil uji $\mathrm{T}$ secara umum ayam hasil persilangan BP (jantan bangkok x jetina petelur) memiliki rataan bobot badan yang lebih besar dibandingkan dengan ayam hasil persilangan PB (jantan petelur $\mathrm{x}$ betina bangkok). Hasil penelitian ini menunjukkan bahwa melalui persilangan bangkok jantan dengan ayam ras petelur betina dapat meningkatkan produktivitasnya, karena persilangan dapat mengurangi gen-gen homozigot dan meningkatkan heterozigositas. Menurut (Warwick et al., 1990) persilangan adalah salah satu alternatif untuk membentuk keturunan yang di harapkan akan memunculkan sifat komplementer (pengaruh saling melengkapi).

\section{HASIL DAN PEMBAHASAN}

Tabel 2. Rataan bobot badan (g) ayam hasil persilangan bp dan pb fase starter

\begin{tabular}{|c|c|c|c|c|c|}
\hline \multirow{2}{*}{$\begin{array}{c}\text { Umur } \\
(\text { Minggu Ke) }\end{array}$} & \multirow[t]{2}{*}{ Jenis Kelamin } & \multicolumn{4}{|c|}{ Hasil Persilangan } \\
\hline & & & $\mathrm{BP}$ & & PB \\
\hline \multirow{3}{*}{1} & Jantan & $\mathrm{n}=21$ & $38,76 \pm 2,39^{a}$ & $\mathrm{n}=18$ & $31,83 \pm 4,67^{\mathrm{b}}$ \\
\hline & Betina & $\mathrm{n}=39$ & $37,00 \pm 2,76^{\mathrm{a}}$ & $\mathrm{n}=42$ & $32,81 \pm 3,64^{b}$ \\
\hline & Jantan dan betina & $\mathrm{n}=60$ & $37,62 \pm 2,74$ & $\mathrm{n}=60$ & $32,52 \pm 3,95$ \\
\hline \multirow{3}{*}{3} & Jantan & $\mathrm{n}=21$ & $89,81 \pm 5,94^{\text {tn }}$ & $\mathrm{n}=18$ & $87,89 \pm 7,41^{\text {tn }}$ \\
\hline & Betina & $\mathrm{n}=38$ & $89,81 \pm 5,94^{\text {tn }}$ & $\mathrm{n}=42$ & $85,95 \pm 5,91^{\text {tn }}$ \\
\hline & Jantan dan betina & $\mathrm{n}=59$ & $88,22 \pm 4,96$ & $n=60$ & $86,53 \pm 6,39$ \\
\hline \multirow{3}{*}{5} & Jantan & $\mathrm{n}=21$ & $265,38 \pm 6,34^{\mathrm{a}}$ & $\mathrm{n}=18$ & $243,44 \pm 23,56^{\mathrm{b}}$ \\
\hline & Betina & $\mathrm{n}=37$ & $256,19 \pm 6,66^{\mathrm{a}}$ & $\mathrm{n}=41$ & $241,34 \pm 14,53^{b}$ \\
\hline & Jantan dan betina & $\mathrm{n}=58$ & $259,50 \pm 7,79$ & $\mathrm{n}=59$ & $241,98 \pm 17,58$ \\
\hline \multirow{3}{*}{7} & Jantan & $\mathrm{n}=21$ & $453,81 \pm 19,86^{\mathrm{a}}$ & $\mathrm{n}=18$ & $396,89 \pm 30,07^{\mathrm{b}}$ \\
\hline & Betina & $\mathrm{n}=37$ & $433,24 \pm 25,69^{\mathrm{a}}$ & $\mathrm{n}=41$ & $377,51 \pm 15,14^{\mathrm{b}}$ \\
\hline & Jantan dan Betina & $\mathrm{n}=58$ & $440,68 \pm 25,58$ & $\mathrm{n}=59$ & $383,42 \pm 22,45$ \\
\hline \multirow{3}{*}{9} & Jantan & $\mathrm{n}=21$ & $648,62 \pm 20,55^{\mathrm{a}}$ & $\mathrm{n}=18$ & $624,56 \pm 32,82^{\mathrm{b}}$ \\
\hline & Betina & $\mathrm{n}=36$ & $624,47 \pm 32,20^{\mathrm{a}}$ & $\mathrm{n}=41$ & $605,15 \pm 33,51^{\mathrm{b}}$ \\
\hline & Jantan dan betina & $\mathrm{n}=57$ & $767,59 \pm 30,56$ & $\mathrm{n}=59$ & $612,42 \pm 31,33$ \\
\hline
\end{tabular}

\section{Panjang Badan}

Hasil pengamatan panjang badan ayam hasil persilangan $\mathrm{PB}$ (jantan ras petelur $\mathrm{x}$ Betina bangkok) dan ayam BP (jantan bangkok $\mathrm{x}$ betina ras petelur) fase starter disajikan pada Tabel 3. 
Tabel 3. Rataan Panjang Badan (cm) Ayam Hasil Persilangan BP dan PB Fase Starter

\begin{tabular}{|c|c|c|c|c|c|}
\hline \multirow{2}{*}{$\begin{array}{c}\text { Umur } \\
\text { (Minggu Ke) }\end{array}$} & \multirow[t]{2}{*}{ Jenis Kelamin } & \multicolumn{4}{|c|}{ Hasil Persilangan } \\
\hline & & & $\mathrm{BP}$ & & PB \\
\hline \multirow{3}{*}{1} & Jantan & $\mathrm{n}=21$ & $4,83 \pm 0,54^{\mathrm{a}}$ & $\mathrm{n}=18$ & $4,36 \pm 0,36^{\mathrm{b}}$ \\
\hline & Betina & $n=39$ & $4,66 \pm 0,53^{\mathrm{a}}$ & $\mathrm{n}=42$ & $4,28 \pm 0,47^{\mathrm{b}}$ \\
\hline & Jantan dan betina & $\mathrm{n}=60$ & $4,72 \pm 0,53$ & $\mathrm{n}=60$ & $4,30 \pm 0,43$ \\
\hline \multirow{3}{*}{3} & Jantan & $\mathrm{n}=21$ & $7,75 \pm 0,41^{\mathrm{a}}$ & $\mathrm{n}=18$ & $7,28 \pm 0,61^{\mathrm{b}}$ \\
\hline & Betina & $\mathrm{n}=38$ & $7,41 \pm 0,35^{\mathrm{a}}$ & $\mathrm{n}=42$ & $7,17 \pm 0,51^{\mathrm{b}}$ \\
\hline & Jantan dan betina & $\mathrm{n}=59$ & $7,54 \pm 0,39$ & $\mathrm{n}=60$ & $7,21 \pm 0,54$ \\
\hline \multirow{3}{*}{5} & Jantan & $\mathrm{n}=21$ & $11,43 \pm 0,79^{a}$ & $\mathrm{n}=18$ & $10,64 \pm 0,26^{\mathrm{b}}$ \\
\hline & Betina & $\mathrm{n}=37$ & $11,29 \pm 0,52^{\mathrm{a}}$ & $\mathrm{n}=41$ & $10,45 \pm 0,20^{\mathrm{b}}$ \\
\hline & Jantan dan betina & $\mathrm{n}=58$ & $11,34 \pm 0,62$ & $\mathrm{n}=59$ & $10,51 \pm 0,23$ \\
\hline \multirow{3}{*}{7} & Jantan & $\mathrm{n}=21$ & $12,72 \pm 0,24^{\mathrm{a}}$ & $\mathrm{n}=18$ & $12,44 \pm 0,32^{b}$ \\
\hline & Betina & $\mathrm{n}=37$ & $12,54 \pm 0,31^{\mathrm{a}}$ & $\mathrm{n}=41$ & $12,19 \pm 0,29^{b}$ \\
\hline & Jantan dan Betina & $\mathrm{n}=58$ & $12,61 \pm 0,29$ & $\mathrm{n}=59$ & $12,26 \pm 0,31$ \\
\hline \multirow{3}{*}{9} & Jantan & $\mathrm{n}=21$ & $14,47 \pm 0,46^{\mathrm{a}}$ & $\mathrm{n}=18$ & $13,94 \pm 0,45^{\mathrm{b}}$ \\
\hline & Betina & $\mathrm{n}=36$ & $14,22 \pm 0,70^{\mathrm{a}}$ & $\mathrm{n}=41$ & $13,47 \pm 0,68^{b}$ \\
\hline & Jantan dan betina & $\mathrm{n}=57$ & $14,35 \pm 0,61$ & $\mathrm{n}=59$ & $13,63 \pm 0,60$ \\
\hline
\end{tabular}

tn = tidak berbeda nyata $(\mathrm{P}>0,05)$

$\mathrm{ab}=$ berbeda nyata $(\mathrm{P}<0,05)$

Berdasarkan hasil uji $\mathrm{T}$ secara umum ayam hasil persilangan BP (jantan bangkok $\mathrm{x}$ betina petelur) memiliki rataan panjang badan yang lebih besar dibandingkan dengan ayam hasil persilangan $\mathrm{PB}$ (jantan petelur $\mathrm{x}$ betina bangkok). Penggunaan tetua betina ras petelur (BP) mewariskan sifat pertumbuhan panjang badan yang lebih cepat dibandingkan ayam tetua betina ayam bangkok (PB). Hal ini sesuai dengan pendapat Daryono et al. (2010), bahwa yang lebih berperan dalam mewariskan sifat pertumbuhan adalah ayam betina. Suprijatna \& Natawihardja (2004), kualitas bibit ayam petelur yaitu memiliki sifat pertumbuhan yang lebih cepat, dewasa kelamin lebih dini dan puncak produksi lebih cepat.

\section{Panjang Shank}

Hasil pengamatan panjang shank ayam hasil persilangan $\mathrm{PB}$ (jantan ras petelur $\mathrm{x}$ betina bangkok) dan ayam BP (jantan bangkok $\mathrm{x}$ betina ras petelur) fase starter disajikan pada Tabel 4.

Tabel 4. Rataan panjang shank (cm) ayam hasil persilangan BP dan PB fase starter

\begin{tabular}{|c|c|c|c|c|c|}
\hline \multirow{2}{*}{$\begin{array}{c}\text { Umur } \\
\text { (Minggu Ke) }\end{array}$} & \multirow[t]{2}{*}{ Jenis Kelamin } & \multicolumn{4}{|c|}{ Hasil Persilangan } \\
\hline & & & $\mathrm{BP}$ & & PB \\
\hline \multirow{3}{*}{1} & Jantan & $\mathrm{n}=21$ & $2,10 \pm 0,20^{\operatorname{tn}}$ & $\mathrm{n}=18$ & $2,08 \pm 0,22^{\text {tn }}$ \\
\hline & Betina & $\mathrm{n}=39$ & $2,06 \pm 0,30^{\mathrm{tn}}$ & $\mathrm{n}=42$ & $2,04 \pm 0,21^{\text {tn }}$ \\
\hline & Jantan dan betina & $\mathrm{n}=60$ & $2,07 \pm 0,27$ & $\mathrm{n}=60$ & $2,05 \pm 0,21$ \\
\hline \multirow{3}{*}{3} & Jantan & $\mathrm{n}=21$ & $2,63 \pm 0,14^{\mathrm{a}}$ & $\mathrm{n}=18$ & $2,52 \pm 0,17^{\mathrm{b}}$ \\
\hline & Betina & $\mathrm{n}=38$ & $2,59 \pm 0,13^{\mathrm{a}}$ & $\mathrm{n}=42$ & $2,46 \pm 0,23^{\mathrm{b}}$ \\
\hline & Jantan dan betina & $\mathrm{n}=59$ & $2,60 \pm 0,13$ & $\mathrm{n}=60$ & $2,47 \pm 0,21$ \\
\hline \multirow{3}{*}{5} & Jantan & $\mathrm{n}=21$ & $4,06 \pm 0,28^{\text {tn }}$ & $\mathrm{n}=18$ & $3,93 \pm 0,10^{\text {tn }}$ \\
\hline & Betina & $\mathrm{n}=37$ & $3,88 \pm 0,26^{\mathrm{a}}$ & $\mathrm{n}=41$ & $3,73 \pm 0,20^{\mathrm{b}}$ \\
\hline & Jantan dan betina & $\mathrm{n}=58$ & $3,90 \pm 0,28$ & $\mathrm{n}=59$ & $3,22 \pm 0,25$ \\
\hline \multirow{3}{*}{7} & Jantan & $\mathrm{n}=21$ & $5,31 \pm 0,25^{\mathrm{a}}$ & $\mathrm{n}=18$ & $4,74 \pm 0,38^{\mathrm{b}}$ \\
\hline & Betina & $\mathrm{n}=37$ & $5,14 \pm 0,26^{\mathrm{a}}$ & $\mathrm{n}=41$ & $4,44 \pm 0,43^{\mathrm{b}}$ \\
\hline & Jantan dan Betina & $\mathrm{n}=58$ & $5,19 \pm 0,26$ & $\mathrm{n}=59$ & $4,53 \pm 0,43$ \\
\hline \multirow{3}{*}{9} & Jantan & $\mathrm{n}=21$ & $6,87 \pm 0,27^{\mathrm{a}}$ & $\mathrm{n}=18$ & $6,23 \pm 0,24^{\mathrm{b}}$ \\
\hline & Betina & $\mathrm{n}=36$ & $6,48 \pm 0,16^{\mathrm{a}}$ & $\mathrm{n}=41$ & $6,25 \pm 0,21^{\mathrm{b}}$ \\
\hline & Jantan dan betina & $\mathrm{n}=57$ & $6,62 \pm 0,27$ & $\mathrm{n}=59$ & $6,24 \pm 0,21$ \\
\hline
\end{tabular}

tn = tidak berbeda nyata $(\mathrm{P}>0,05)$

ab = berbeda nyata $(\mathrm{P}<0,05)$ 
Berdasarkan Tabel 4. Terlihat ayam hasil persilangan pada 1 minggu memiliki panjang shank yang tidak berbeda $(\mathrm{P}>0,05)$ baik pada keturunan (F1) jantan maupun betina, namun pada umur 5 minggu dihasilkan panjang shank yang tidak berbeda $(\mathrm{P}>0,05)$ hanya pada keturunan (F1) ayam jantan. Sedangkan ayam hasil persilangan pada umur 3,7 dan 9 minggu baik jantan maupun betina, serta umur 4 minggu betina memiliki panjang shank yang berbeda nyata $(\mathrm{P}<0,05)$. Hal ini menunjukkan bahwa secara umum ayam BP pada umur 3-9 minggu memiliki pertumbuhan tulang shank yang lebih besar dibandingkan ayam PB. Secara umum ukuran panjang shank hasil persilangan PB dan BP pada ayam jantan cenderung lebih panjang dibandingkan dengan betina. Secara genetik ekspresi gen cGH yang mengontrol sifat produksi pada ayam jantan cenderung lebih tinggi dibandingkan pada ayam betina (Pagala et al., 2015).

\section{Panjang Rentang Sayap}

Hasil pengamatan panjang rentang sayap ayam hasil persilangan $\mathrm{PB}$ (jantan ras petelur $\mathrm{x}$ betina bangkok) dan ayam BP (jantan bangkok $\mathrm{x}$ betina ras petelur) fase starter disajikan pada Tabel 5.

Tabel 5. Rataan panjang rentang sayap $(\mathrm{cm})$ ayam hasil persilangan BP dan PB fase starter

\begin{tabular}{|c|c|c|c|c|c|}
\hline \multirow{2}{*}{$\begin{array}{c}\text { Umur } \\
\text { (Minggu Ke) }\end{array}$} & \multirow[t]{2}{*}{ Jenis Kelamin } & \multicolumn{4}{|c|}{ Hasil Persilangan } \\
\hline & & & BP & & PB \\
\hline \multirow{3}{*}{1} & Jantan & $\mathrm{n}=21$ & $3,99 \pm 0,59^{\mathrm{a}}$ & $\mathrm{n}=18$ & $3,39 \pm 0,31^{\mathrm{b}}$ \\
\hline & Betina & $\mathrm{n}=39$ & $3,99 \pm 0,40^{\mathrm{a}}$ & $\mathrm{n}=42$ & $3,57 \pm 0,43^{\mathrm{b}}$ \\
\hline & Jantan dan betina & $\mathrm{n}=60$ & $3,99 \pm 0,47$ & $\mathrm{n}=60$ & $3,52 \pm 0,40$ \\
\hline \multirow{3}{*}{3} & Jantan & $\mathrm{n}=21$ & $6,65 \pm 0,57^{\text {tn }}$ & $\mathrm{n}=18$ & $6,51 \pm 0,37^{\text {tn }}$ \\
\hline & Betina & $\mathrm{n}=38$ & $6,84 \pm 0,33^{\text {tn }}$ & $\mathrm{n}=42$ & $6,76 \pm 0,61^{\text {tn }}$ \\
\hline & Jantan dan betina & $\mathrm{n}=59$ & $6,68 \pm 0,43$ & $n=60$ & $6,77 \pm 0,56$ \\
\hline \multirow{3}{*}{5} & Jantan & $\mathrm{n}=21$ & $10,21 \pm 0,60^{\mathrm{a}}$ & $\mathrm{n}=18$ & $9,38 \pm 0,34^{\mathrm{b}}$ \\
\hline & Betina & $n=37$ & $11,13 \pm 0,81^{\mathrm{a}}$ & $\mathrm{n}=41$ & $9,92 \pm 0,95^{\mathrm{b}}$ \\
\hline & Jantan dan betina & $\mathrm{n}=58$ & $10,80 \pm 0,86$ & $\mathrm{n}=59$ & $9,75 \pm 0,85$ \\
\hline \multirow{3}{*}{7} & Jantan & $\mathrm{n}=21$ & $12,04 \pm 0,62^{\mathrm{tn}}$ & $\mathrm{n}=18$ & $11,94 \pm 0,79^{\text {tn }}$ \\
\hline & Betina & $\mathrm{n}=37$ & $13,72 \pm 0,93^{\mathrm{a}}$ & $\mathrm{n}=41$ & $13,34 \pm 0,63^{\mathrm{b}}$ \\
\hline & Jantan dan Betina & $\mathrm{n}=58$ & $13,11 \pm 1,15$ & $\mathrm{n}=59$ & $12,91 \pm 0,93$ \\
\hline \multirow{3}{*}{9} & Jantan & $\mathrm{n}=21$ & $14,42 \pm 0,75^{\mathrm{b}}$ & $\mathrm{n}=18$ & $15,16 \pm 0,62^{\mathrm{a}}$ \\
\hline & Betina & $\mathrm{n}=36$ & $16,01 \pm 1,28^{\mathrm{b}}$ & $\mathrm{n}=41$ & $16,80 \pm 1,26^{\mathrm{a}}$ \\
\hline & Jantan dan betina & $\mathrm{n}=57$ & $16,01 \pm 1,55$ & $\mathrm{n}=59$ & $15,50 \pm 0,95$ \\
\hline $\begin{array}{ll}\mathrm{tn} \\
\mathrm{ab}\end{array}$ & $\begin{array}{l}\text { eda nyata }(\mathrm{P}>0,05) \\
\text { yata }(\mathrm{P}<0,05)\end{array}$ & & & & \\
\hline
\end{tabular}

Panjang rentang sayap ayam BP secara umum memiliki rataan yang lebih tinggi dibandingkan dengan ayam PB. Hal ini sesuai dengan pendapat Pagala et al. (2015) bahwa keragaman sifat produksi hewan disebabkan oleh faktor genetik dan lingkungan. Noor (2000) menambahkan bahwa perbedaan yang dapat diamati pada ternak untuk berbagai sifat disebabkan oleh faktor genetik dan lingkungan.

Menurut Zainal et al. (2012), ayam yang memiliki hubungan kekerabatan jauh dapat terjadi heterosis positif. Persilangan dengan sesama ayam lokal menghasilkan bobot badan yang lebih ringan dibandingkan dengan tetuanya. Sedangkan menurut Banjarnahor et al. (2014), ternak yang memiliki hubungan kekerabatan dekat memiliki peluang yang kecil untuk meningkatkan heterosis dalam persilangannya.

\section{Lingkar dada}

Data hasil pengukuran lingkar dada ayam hasil persilangan $\mathrm{PB}$ dan $\mathrm{BP}$ fase starter disajikan pada Tabel 6.Secara umum ukuran lingkar dada ayam BP fase starter mempunyai nilai rataan lebih tinggi jika dibandingkan dengan ayam PB. Perbedaan yang terjadi ini disebabkan adanya peningkatan pertumbuhan ayam yang berbeda, perbedaan yang ada lebih disebabkan dominan karena faktor genetik,dan faktor lingkungan yang relatif lebih kecil. Hal ini sesuai dengan pendapat Putri (2010), bahwa penampilan sifat-sifat kuantitatif pada ukuran tubuh dipengaruhi oleh faktor genetik dan lingkungan serta interaksi kedua faktor tersebut. 
Tabel 6. Rataan lingkar dada $(\mathrm{cm})$ ayam hasil persilangan BP dan PB fase starter

\begin{tabular}{|c|c|c|c|c|c|}
\hline \multirow{2}{*}{$\begin{array}{c}\text { Umur } \\
\text { (Minggu Ke) }\end{array}$} & \multirow[t]{2}{*}{ Jenis Kelamin } & \multicolumn{4}{|c|}{ Hasil Persilangan } \\
\hline & & & BP & & $\mathrm{PB}$ \\
\hline \multirow{3}{*}{1} & Jantan & $\mathrm{n}=21$ & $6,54 \pm 1,37^{\mathrm{tn}}$ & $\mathrm{n}=18$ & $6,26 \pm 0,50^{\text {tn }}$ \\
\hline & Betina & $\mathrm{n}=39$ & $6,05 \pm 1,11^{\text {tn }}$ & $\mathrm{n}=42$ & $5,90 \pm 0,54^{\mathrm{tn}}$ \\
\hline & Jantan dan betina & $\mathrm{n}=60$ & $6,22 \pm 1,21^{\text {tn }}$ & $\mathrm{n}=60$ & $6,01 \pm 0,54^{\text {tn }}$ \\
\hline \multirow{3}{*}{3} & Jantan & $\mathrm{n}=21$ & $9,90 \pm 1,32^{\mathrm{a}}$ & $\mathrm{n}=18$ & $9,21 \pm 0,65^{b}$ \\
\hline & Betina & $\mathrm{n}=38$ & $9,67 \pm 0,42^{\mathrm{a}}$ & $\mathrm{n}=42$ & $9,04 \pm 0,58^{b}$ \\
\hline & Jantan dan betina & $\mathrm{n}=59$ & $9,75 \pm 0,39^{\mathrm{a}}$ & $\mathrm{n}=60$ & $9,10 \pm 0,59^{\mathrm{a}}$ \\
\hline \multirow{3}{*}{5} & Jantan & $\mathrm{n}=21$ & $13,11 \pm 0,14^{\mathrm{a}}$ & $\mathrm{n}=18$ & $12,67 \pm 0,14^{\mathrm{b}}$ \\
\hline & Betina & $\mathrm{n}=37$ & $12,60 \pm 0,51^{\mathrm{a}}$ & $\mathrm{n}=41$ & $12,27 \pm 0,15^{\mathrm{b}}$ \\
\hline & Jantan dan betina & $\mathrm{n}=58$ & $12,56 \pm 0,28^{a}$ & $\mathrm{n}=59$ & $12,39 \pm 0,24^{b}$ \\
\hline \multirow{3}{*}{7} & Jantan & $\mathrm{n}=21$ & $15,92 \pm 0,32^{\mathrm{a}}$ & $\mathrm{n}=18$ & $15,23 \pm 0,87^{\mathrm{b}}$ \\
\hline & Betina & $\mathrm{n}=37$ & $14,42 \pm 0,50^{\mathrm{a}}$ & $\mathrm{n}=41$ & $15,10 \pm 0,74^{\mathrm{b}}$ \\
\hline & Jantan dan Betina & $\mathrm{n}=58$ & $15,59 \pm 0,50^{a}$ & $\mathrm{n}=59$ & $15,14 \pm 0,77^{\mathrm{b}}$ \\
\hline \multirow{3}{*}{9} & Jantan & $\mathrm{n}=21$ & $20,35 \pm 0,65^{a}$ & $\mathrm{n}=18$ & $19,67 \pm 0,83^{\mathrm{b}}$ \\
\hline & Betina & $\mathrm{n}=36$ & $19,66 \pm 0,84^{\mathrm{a}}$ & $\mathrm{n}=41$ & $18,67 \pm 1,09^{\mathrm{b}}$ \\
\hline & Jantan dan betina & $\mathrm{n}=57$ & $19,95 \pm 0,83^{\mathrm{a}}$ & $\mathrm{n}=59$ & $19,01 \pm 1,08^{b}$ \\
\hline
\end{tabular}

Berdasarkan data Tabel 6, menunjuk-kan ukuran lingkar dada akan terus meningkat sejalan dengan bertambahnya umur ayam, dimana otot dada merupakan otot yang cukup responsif dengan faktor pakan, Sebagaimana hasil penelitian oleh Kita et al. (2002) bahwa bagian tubuh ayam yang paling respon terhadap kondisi makanan adalah otot dada (muscuus pectoralis) lalu diikuti oleh otot paha. Berdasarkan data pertambahan lingkar dada menurut jenis kelamin, ayam hasil persilangan ayam BP dan PB pada ayam jantan mempunyai pertumbuhan yang lebih besar.

\section{Pertumbuhan}

Hasil pengamatan pertumbuhan ayam hasil persilangan $\mathrm{PB}$ (jantan ras petelur $\mathrm{x}$ betina bangkok) dan ayam BP (jantan bangkok $\mathrm{x}$ betina ras petelur) fase starter disajikan pada Tabel 7. Hasil penelitian menunjukkan bahwa ayam BP memiliki pertumbuhan yang lebih tinggi dibandingkan dengan ayam PB. Ayam hasil persilangan $\mathrm{BP}$ memiliki potensi cukup besar sebagai sumber genetik pada sifat pertumbuhan ditunjukkan dengan kemampuannya mimiliki kinerja pertumbuhan ayam yang lebih besar dibandingkan ayam PB. Hal ini disebabkan adanya hormon insulin yang mengatur metabolisme. Hormon insulin diketahui memiliki peran dalam mempartisi substrat yang berasal dari makanan ke dalam sel tubuh yang sedang berkembang dan pada saat proses katabolisme berlangsung. Hormon insulin yang tinggi pada tubuh dapat dijadikan indikator pertumbuhan dan perkembangan tubuh ayam (Daryono et al.., 2010).

Ukuran-ukuran tubuh ayam jantan lebih tinggi dibandingkan ayam betina. Hal ini dikarenakan ayam jantan memiliki hormon pengatur pertumbuhan yang lebih tinggi dibandingkan betina. Bobot badan ayam jantan jauh lebih tinggi daripada betina sebagai akibat dari adanya hormone testoteron yang berfungsi sebagai steroid androgen yakni pengatur pertumbuhan. Sekresi steroid yang tinggi pada jantan ini sebagai dampak dari tingginya sekresi hormon testoteron yang diproduksi oleh testis, sehingga laju pertumbuhan pada ayam jantan lebih tinggi dibandingkan pada ayam betina (Hapsari, 2015). 
Tabel 7. Rataan pertumbuhan ayam hasil persilangan BP dan PB perminggu

\begin{tabular}{|c|c|c|c|c|c|c|c|c|c|c|c|c|}
\hline \multirow{2}{*}{\multicolumn{2}{|c|}{ Parameter }} & \multirow{2}{*}{$\mathrm{BP} / \mathrm{PB}$} & \multicolumn{8}{|c|}{ Umur (Minggu) } & \multirow{2}{*}{ Total } & \multirow{2}{*}{$\begin{array}{c}\text { Total } \\
\vdots / 9\end{array}$} \\
\hline & & & 1 & 2 & 3 & 4 & 5 & 6 & 7 & 8 & & \\
\hline \multirow{4}{*}{$\mathrm{BB}$} & \multirow{2}{*}{ Jantan } & $\mathrm{BP}$ & 17,10 & 33,95 & 33,05 & 92,52 & 97,43 & 91,00 & 90,43 & 104,38 & 609,86 & \multirow{2}{*}{1202,60} \\
\hline & & PB & 15,67 & 40,39 & 78,89 & 76,67 & 66,56 & 86,89 & 99,61 & 128,06 & 592,74 & \\
\hline & \multirow{2}{*}{ Betina } & BP & 18,44 & 31,91 & 80,76 & 88,08 & 98,59 & 78,46 & 92,53 & 97,86 & 586,63 & \multirow{2}{*}{1158,46} \\
\hline & & PB & 8,90 & 44,24 & 73,52 & 81,87 & 61,66 & 74,51 & 100,17 & 126,96 & 571,83 & \\
\hline \multirow{4}{*}{ PB } & \multirow{2}{*}{ Jantan } & $\mathrm{BP}$ & 0,84 & 2,07 & 1,94 & 1,75 & 1,14 & 0,15 & 1,19 & 0,56 & 9,64 & \multirow{2}{*}{19,42} \\
\hline & & $\mathrm{PB}$ & 0,85 & 2,28 & 2,28 & 1,08 & 0,85 & 0,94 & 1,06 & 0,44 & 9,78 & \\
\hline & \multirow{2}{*}{ Betina } & $\mathrm{BP}$ & 0,86 & 1,91 & 1,95 & 1,90 & 0,88 & 0,38 & 0,90 & 0,82 & 9,60 & \multirow{2}{*}{18,42} \\
\hline & & PB & 0,69 & 1,83 & 1,83 & 1,46 & 0,95 & 0,79 & 0,96 & 0,31 & 8,82 & \\
\hline \multirow{4}{*}{ PS } & \multirow{2}{*}{ Jantan } & $\mathrm{BP}$ & 0,19 & 0,34 & 0,72 & 0,70 & 0,38 & 0,88 & 1,08 & 0,48 & 4,77 & \multirow{2}{*}{8,92} \\
\hline & & PB & 0,16 & 0,29 & 0,34 & 0,57 & 0,71 & 0,59 & 0,73 & 0,76 & 4,15 & \\
\hline & \multirow{2}{*}{ Betina } & $\mathrm{BP}$ & 0,13 & 0,40 & 0,65 & 0,64 & 0,61 & 0,64 & 1,06 & 0,30 & 4,43 & \multirow{2}{*}{8,62} \\
\hline & & PB & 0,14 & 0,27 & 0,27 & 0,41 & 0,78 & 0,52 & 0,66 & 1,14 & 4,19 & \\
\hline \multirow{4}{*}{ LD } & \multirow{2}{*}{ Jantan } & $\mathrm{BP}$ & 1,31 & 2,05 & 2,12 & 1,10 & 1,22 & 1,59 & 1,67 & 2,76 & 13,82 & \multirow{2}{*}{27,22} \\
\hline & & $\mathrm{PB}$ & 1,42 & 1,52 & 2,22 & 1,24 & 1,37 & 1,19 & 1,73 & 2,71 & 13,40 & \\
\hline & \multirow{2}{*}{ Betina } & BP & 1,54 & 2,08 & 2,14 & 0,79 & 1,53 & 1,28 & 1,95 & 2,30 & 13,61 & \multirow{2}{*}{26,37} \\
\hline & & PB & 0,52 & 2,61 & 2,31 & 0,92 & 1,49 & 1,34 & 1,50 & 2,07 & 12,76 & \\
\hline \multirow{4}{*}{ PRs } & \multirow{2}{*}{ Jantan } & BP & 0,50 & 2,17 & 1,65 & 1,91 & 1,02 & 0,80 & 1,19 & 1,19 & 10,43 & \multirow{2}{*}{22,20} \\
\hline & & PB & 1,13 & 1,98 & 1,46 & 1,41 & 1,59 & 0,98 & 1,05 & 2,17 & 11,77 & \\
\hline & \multirow{2}{*}{ Betina } & $\mathrm{BP}$ & 0,76 & 2,09 & 2,06 & 2,24 & 1,52 & 1,07 & 1,34 & 0,90 & 11,98 & \multirow{2}{*}{24,11} \\
\hline & & PB & 0,99 & 2,19 & 1,50 & 1,66 & 1,38 & 2,04 & 0,98 & 1,39 & 12,13 & \\
\hline \multicolumn{2}{|c|}{ Keterangan } & $\begin{array}{l}\text { BB } \\
\text { PS : } \\
\text { PRs }\end{array}$ & $\begin{array}{l}\text { Bobot } \\
\text { anjan }\end{array}$ & $\begin{array}{l}\text { dan } \\
\text { hank } \\
\text { Renta }\end{array}$ & $C$ & & $\begin{array}{l}\mathrm{B}: \text { Pan } \\
\mathrm{D}: \mathrm{Lin}\end{array}$ & $\begin{array}{l}\text { jang } \mathrm{Ba} \\
\text { gkar D. }\end{array}$ & dan & & & \\
\hline
\end{tabular}

\section{KESIMPULAN}

Ukuran dimensi tubuh ayam BP hasil persilangan jantan ayam bangkok dengan betina ayam petelur lebih tinggi dibandingkan ayam PB yakni hasil persilangan jantan ayam petelur dengan betina ayam bangkok). Untuk meningkatkan performa produksi daging baiknya menggunakan persilangan ayam bangkok jantan dengan ayam petelur.

\section{DAFTAR PUSTAKA}

Banjarnahor N., U. Budi, \& Hamdan. 2014. Estimasi jarak genetik dan faktor peubah pembeda bangsa babi (berkshire, duroc, landrace, dan yorkshire) melalui analisis morfometrik di BPTU babi dan kerbau siborong-borong. JPI 2(2):165-167.

Daryono, B.S., I. Roosdianto, \& H.T.S. Saragih. 2010. Pewarisan karakter fenotip ayam hasil persilangan ayam pelung dengan ayam cemani. Jurnal Veteteriner 11(4):257-273.

Hapsari, I.P. 2015. Ukuran tubuh dan produksi telur ayam hasil persilangan ayam lokal dengan ayam ras pedaging. Skripsi. Bogor. Institut Pertanian Bogor.
Nataamijaya, A.G. 2005. Karakteristik penampilan pola warna bulu, kulit, sisik kaki, dan paruh ayam Pelung di Garut dan ayam Sentul di Ciamis. Buletin Plasma Nutfah 11(1):2-5.

Nataamijaya, A.G. 2010. Pengembangan potensi ayam lokal untuk menunjang peningkatan kesejahteraan petani. Jurnal Litbang Pertanian. 29(4):131-138.

Noor, R, R. 2008. Genetika Ternak. Penebar Swadaya. Jakarta

Pagala, M.A., A.M. Tasse, \& N. Ulupi. 2015. Association of cGH EcoRV Gene with Production in Tolaki Chicken. IJSBAR 24(7):88-95.

Putri, D.A. 2010. Karakteristik Kualitatif dan Kuantitatif Ayam Leher Gundul (Legund) di Kabupaten Subang dan Bogor, Jawa Barat. Fakultas Peternakan IPB. Bogor.

Suprijatna, E. \& D. Natawihardja. 2004. Pengaruh taraf protein dalam ransum pada periode pertumbuhan terhadap performans ayam ras petelur tipe medium saat awal peneluran. Jurnal Pengembangan Peternakan Tropis 29(1) :33-38. 
Steel, R.G.D. \& J.H. Torrie. 1995. Prinsip dan Prosedur Statistika. Penterjemah Bambang Sumantri. Gramedia Pustaka. Jakarta.

Tarigan, R.T. 2010. Karakteristik Sifat Kualitatif dan Kuantitatif Ayam Walik di Sumedang dan Bogor. Fakultas Peternakan, IPB. Bogor.

Zainal H, T. Sartika, D. Zainuddin, \& Komarudin. 2012. Persilangan pada Ayam Lokal (KUB, Sentul, Gaok) untuk Meningkatkan Produksi Daging Unggas Nasional. Workshop Nasional Unggas Lokal. Balai Penelitian Ternak. Bogor.

Warwick, E.J., J.M. Astuti, \& W. Hardjosubroto 1990. Pemuliaan Ternak. Gadjah Mada University Press. Yogyakarta. 